\title{
Analysis of Spatial and Temporal Dynamics of Land Use Land Cover Change in Port Harcourt Areas of River State
}

\author{
Enete, I.C ${ }^{1} \quad$ Ezezue, A.M ${ }^{2} \quad$ Nnah, Benita ${ }^{1}$ \\ 1.Dept. of Geography \& Meteorology, Faculty of Environmental Sciences, Nnamdi Azikiwe University, Awka, \\ Nigeria \\ 2.Dept. of Architecture, Faculty of Environmental Sciences, Nnamdi Azikiwe University, Awka, Nigeria
}

\begin{abstract}
It is estimated that by the year 2050, half of the world will be urbanized and developing countries will be leading the crusade. This rapid urbanization will put more pressure on environmental system. The traditional in-situ assessment of land change will no longer be feasible because of increased urbanization. This study assessed the land use/ land cover dynamics in Port Harcourt city of River State. Land-use classification and change detection was conducted using multiple satellite data sources (Landsat TM, ETM) of Port Harcourt city for 1986, 2003 and 2018. Kappa statistical too and ArcGIS Software were also employed for further analysis. The key findings showed that urbanization was rapid and exponential. These observed urbanization occurred due to conversion of forest reserves, agricultural lands and water bodies to urban land.
\end{abstract}

Keywords: Land use, Land cover, Satellite, Imagery, Urbanization, Port Harcourt

DOI: $10.7176 / \mathrm{JEES} / 10-6-05$

Publication date:June $30^{\text {th }} 2020$

\section{Introduction.}

It has been projected that cities will accommodate about $70 \%$ of the global population by 2050 (UN, 2012); Compared to the current urbanization rate of $50 \%$. Such rate of rapid urbanization means higher densities in existing cities and many newer urban areas to accommodate up to 2 billion new urban dwellers. However, the rapid urban development in fast-growing cities has resulted in the cities overlooking the environmental and social aspects of urban life (Du et al., 2012; Zanganeh et al., 2011). A considerable amount of natural landscape is transformed into building mass and hard surfaces, creating environmental threats for existing and future cities.

Satellite remote sensing collects multispectral, multi resolution and multi temporal data, and turns them into information valuable for understanding and monitoring urban land processes.

The use of remotely sensed data has been widely applied as a tool to effectively study the extent of LULC in many cities across the world (Shalaby and Tateishi, 2007; kafi et al., 2013). These studies have acknowledged that remotely sensed LST can provide a spatially continuous data over a whole city or region, permitting visualization of spatial relationships between temperature patterns and urban land uses (Enete, 2009; Enete et al., 2016).

The study, therefore seeks to assess the spatial and temporal dynamics in land use land cover changes in Port Harcourt L.G.A from 1986 to 2018 using geospatial techniques.

\subsection{Study Area.}

Port-Harcourt L.G.A is positioned between Latitudes $4^{0} 45^{\prime} \mathrm{N}$, and $4^{0} 55^{\prime} \mathrm{N}$ and Longitudes $6^{0} 55^{\prime} \mathrm{E}$ and $7^{0} 05^{\prime} \mathrm{E}$. Port-Harcourt is located at about $25 \mathrm{~km}$ from the Atlantic Ocean and it is situated between the Dockyard Creek/Bonny River and the Amadi Creek (Okoye, 1975;

Oyegunet al., 1999). Port-Harcourt, originally known, as "Igwe-Ocha" was founded in 1913 by the British in an area traditionally inhabited by the Ikweres. It was named after Lewis Viscount Harcourt, the then Secretary of State of Colonies. The main City of Port Harcourt is the Port-Harcourt City Local Government Area. It serves as the Headquarters of Rivers State (Alagoaet al., 2002). It is bounded to the north by Obio-Akpor LGA, to the west by Degema L.G.A, to the south by Okrika L.G.A, and to the east by Eleme L.G.A (Fig. 1 and 2). 


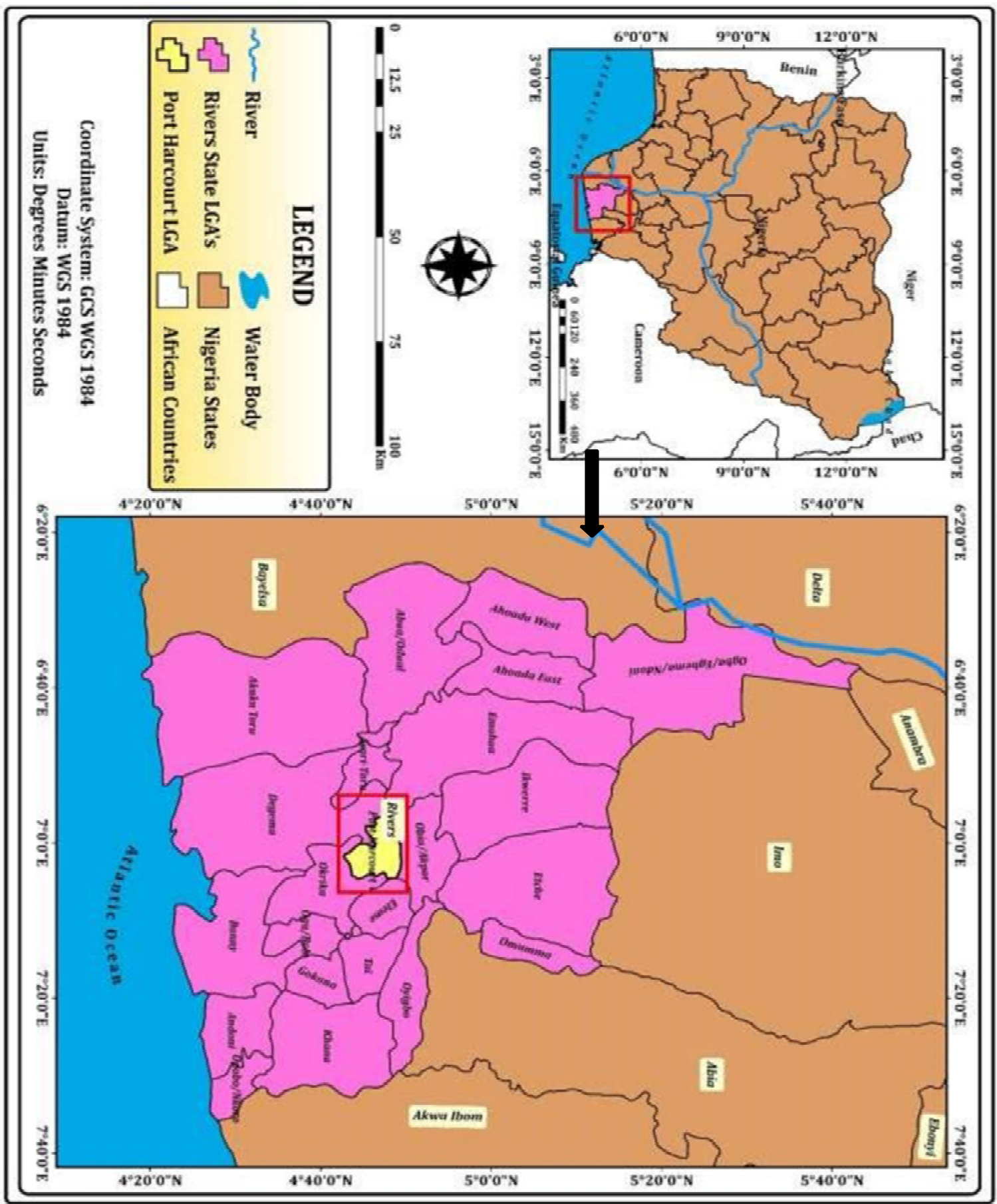

Figure 1.1. Map of Rivers State showing Port Harcourt LGA with inset of Nigeria showing Rivers State 


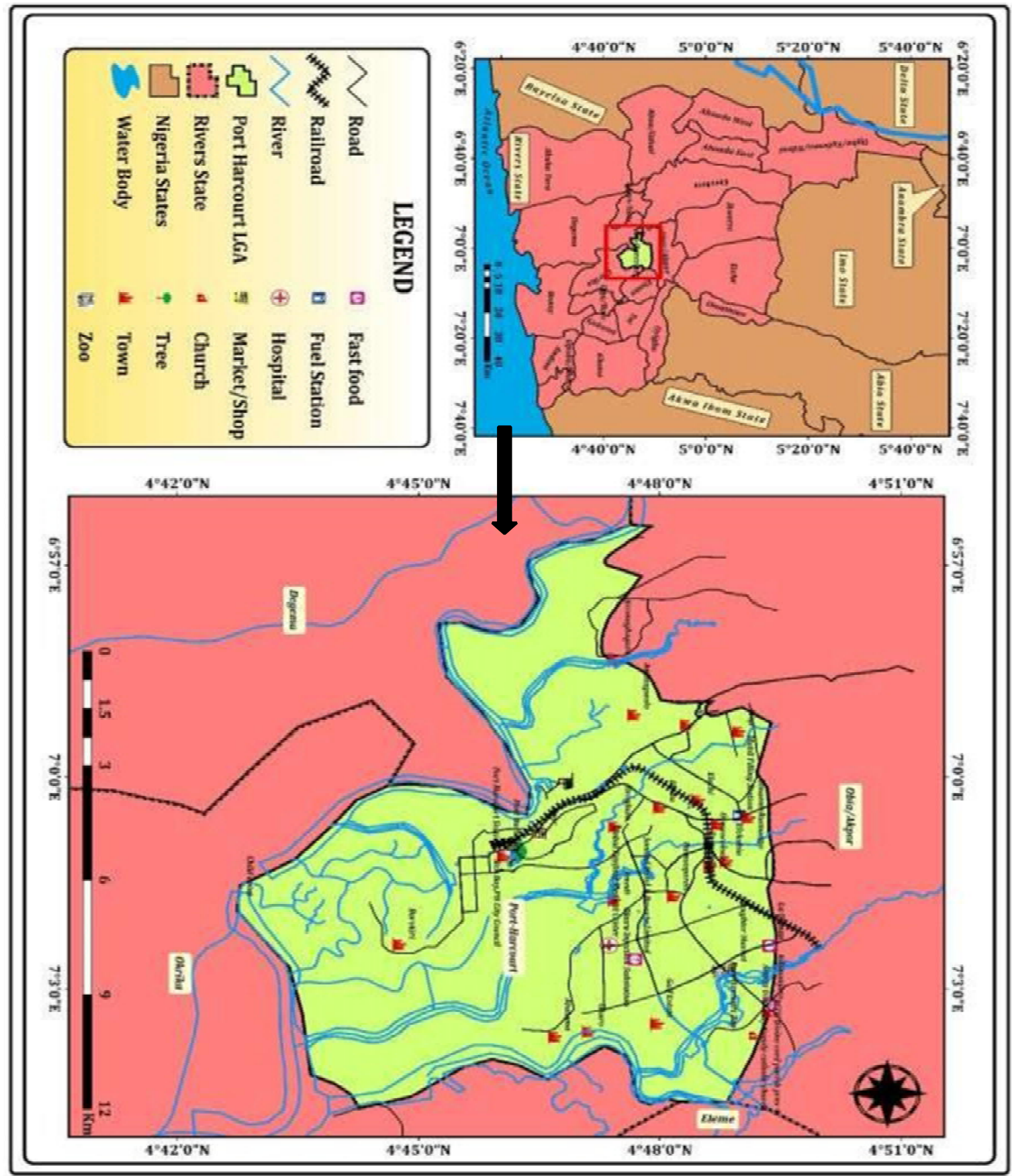

Figure 1. Map of Port Harcourt LGA with inset of Rivers State showing Port Harcourt LGA

\subsection{Research Design}

The study was a satellite based assessment of the land use and land cover of Port Harcourt. The study adopted the post- classification change detection approach for analysing historical land use land cover changes. Four major steps were followed in analysing historical land use land cover changes: data acquisition, image enhancement, supervised classification and detection analysis. These steps can be grouped under the pre-processing, classification and post-classification stages as outlined by (Singh, 1989; Nagi, 2011):

1. Pre-processing: Satellite data and Guide map, Image Enhancement of satellite.

2. Classification: Supervised Classification.

3. Post- Processing: Classified LULC Maps, Change Detection Analysis, Final Output. 


\subsection{Data Requirements}

Due to the remote-sensing approach of this research, the data required for the study are majorly remotely-sensed satellite imagery which include;

1. Medium resolution satellite data for Land Use/Land Cover analysis, and spatial LST extraction from 1986 to 2018

2. Updated State and Local Government boundary vector shape file 2016

\subsection{Sources of Data}

The secondary data for this study are satellite imagery, relevant journals, texts and online articles. The main satellite imagery used is LANDSAT data, which provides high spatial resolution. LANDSAT imagery was chosen for this study because they are available at no cost and have been found to be significant in the study of environmental changes (Abd El-kawy et al., 2011).

The ancillary data used in this study include an administrative shape file of the Port Harcourt LGA acquired from the Office of the Surveyor General of the Federation (OSGOF), information on the physical and socioeconomic variables of the city and historical records are gotten mostly from web sources that are affiliated to the region.

\subsection{Method of Data Analysis}

\subsubsection{Image Classification}

The LANDSAT data were captured under clear conditions ( $0 \%$ cloud coverage for all the images), hence uniform atmospheric conditions within the images were assumed and no atmospheric corrections were applied. All the images were pre-processed by the USGS to rectify any geometric or radiometric distortions of the image. For the Landsat TM, ETM+ and OLI, a False Colour Composite (FCC) operation was performed using the ArcGIS 10.4 software and the images were combined in the order of band 5, 4 and 3 for Landsat TM and ETM+ while that of Landsat OLI was in the order of band 6,5 and 3 due to change in sensor. The images were then clipped to the boundary of Port Harcourt to allow for accuracy.

A supervised classification scheme with the Interactive Selection algorithm was used for the classification. The supervised classification was performed by creating a training sample, and based on spectral signature curve, various land-use classes were created namely: Water body, Urban Area, Bare Surface, Vegetative Cover. These classes were observed distinctively on the clipped image and were used for the classification. Table 1 shows the characteristics of these classes and the colours assigned to them.

Table .1.Land Use/Land Cover classes and descriptions.

\begin{tabular}{|c|c|c|c|c|c|}
\hline CLASS & $\begin{array}{l}\text { LAND } \\
\text { USE }\end{array}$ & DESCRIPTION & EXAMPLES & $\begin{array}{l}\text { OBSERVED } \\
\text { COLOUR }\end{array}$ & $\begin{array}{l}\text { ASSIGNED } \\
\text { COLOUR }\end{array}$ \\
\hline 1 & $\begin{array}{l}\text { Water } \\
\text { Body }\end{array}$ & Surface water bodies & $\begin{array}{l}\text { River, permanent open water, } \\
\text { lakes, ponds, canals, } \\
\text { permanent/seasonal wetlands, } \\
\text { low-lying areas, marshy land, } \\
\text { and swamps. }\end{array}$ & Navy Blue & Blue \\
\hline 2 & $\begin{array}{l}\text { Urban } \\
\text { Areas }\end{array}$ & $\begin{array}{l}\text { Impervious surfaces } \\
\text { that do not allow } \\
\text { infiltration of water }\end{array}$ & $\begin{array}{l}\text { All infrastructure- residential, } \\
\text { commercial, mixed use and } \\
\text { industrial areas, villages, } \\
\text { settlements, road network, } \\
\text { pavements, and man-made } \\
\text { structures. }\end{array}$ & $\begin{array}{c}\text { Cyan blue, } \\
\text { Purple, white }\end{array}$ & Red \\
\hline 3 & $\begin{array}{l}\text { Bare } \\
\text { Surface }\end{array}$ & $\begin{array}{c}\text { Includes all open } \\
\text { grounds that are } \\
\text { neither vegetated nor } \\
\text { built-up, } \\
\text { untarred roads and } \\
\text { footpaths. }\end{array}$ & $\begin{array}{l}\text { Fallow land, earth and sand } \\
\text { land in-fillings, } \\
\text { construction sites, developed } \\
\text { land, excavation sites, open } \\
\text { space, bare soils, and the } \\
\text { remaining land cover types. }\end{array}$ & $\begin{array}{l}\text { Light and dark } \\
\text { brown, cream. }\end{array}$ & Cream \\
\hline 4 & $\begin{array}{l}\text { Vegetative } \\
\text { Cover }\end{array}$ & $\begin{array}{l}\text { This includes all } \\
\text { plants along } \\
\text { river channels, } \\
\text { forests, parks and } \\
\text { reserves, farmland } \\
\text { etc. }\end{array}$ & $\begin{array}{l}\text { Trees, natural vegetation, } \\
\text { mixed forest, gardens, parks } \\
\text { and playgrounds, grassland, } \\
\text { vegetated lands, agricultural } \\
\text { lands, and crop fields. }\end{array}$ & $\begin{array}{l}\text { Light, lemon } \\
\text { and dark green }\end{array}$ & Green \\
\hline
\end{tabular}




\subsubsection{Retrieval of Land Surface Temperature (LST) From LANDSAT Images}

The mono-window algorithm method was adopted to retrieve the LST from the imageries selected for this study. The Landsat-5 TM thermal band $6(10.40-12.50 \mu \mathrm{m})$, ETM+ band 6L $(10.4-12.5 \mu \mathrm{m})$ and TIRS 10 and $11(10.60$ $-11.19 \mu \mathrm{m}$ ) have a spatial resolution of $30 \mathrm{~m}$ respectively which is considered suitable as shown by many literatures for capturing the multifaceted intra-urban temperature differences thus making it effective for urban climate analysis. For the Landsat ETM+ sensor, images in the thermal band are taken twice: one in the low-gain mode (band 6L) and the other in the high-gain mode (band 6H). Band 6L is used to image surfaces with high brightness, whereas band $6 \mathrm{H}$ is for low brightness. Band $6 \mathrm{~L}$ was used in this study, due to errors contained in the $6 \mathrm{H}$ band. Consequently, the LANDSAT thermal bands were used to retrieve LST over the study area for the three different periods (1986, 2003, and 2018) based on the following steps:

\section{STEP 1. Conversion of Digital Numbers (DN) of the bands to Spectral Radiance}

The DN of the thermal bands of TM and ETM+ were converted into spectral radiance values for each of the investigated years using the following equation -

$$
L \lambda=(Q \longrightarrow C A L M A X L M A X--L Q M I N C A L M I N) \times(D N-1)+L M I N
$$

Where;

$\mathrm{L} 1=$ the spectral radiance at the sensor's aperture in $\mathrm{Wm}^{-2} \mathrm{sr}^{-1} \mu \mathrm{m}^{-1}$

$\mathrm{L}_{\mathrm{MAX}}=$ Spectral radiance scaled to $\mathrm{Q}_{\mathrm{CALMAX}}$ in $\mathrm{Wm}^{-2} \mathrm{Sr}^{-1} \mu \mathrm{m}^{-1}$, available in the metadata.

$\mathrm{L}_{\mathrm{MIN}}=$ Spectral radiance scaled to $\mathrm{Q}_{\mathrm{CALMIN}}$ in $\mathrm{Wm}^{-2} \mathrm{sr}^{-1} \mu \mathrm{m}^{-1}$, available in the metadata.

$\mathrm{Q}_{\text {CALMAX }}=$ Maximum quantized calibrated pixel value (corresponding to $\mathrm{L}_{\mathrm{MAX}}$ ) in $\mathrm{DN}=255 \mathrm{Q}_{\mathrm{CALMIN}}=$ Minimum quantized calibrated pixel value (corresponding to $\mathrm{L}_{\mathrm{MIN}}$ ) in $\mathrm{DN}=1$

$\mathrm{DN}=$ Digital Number of the Band

For Landsat 8 with file data on Radiance Multiplier (M) and Radiance Add (B), the thermal infrared (TIR) band was converted into spectral radiance (L $\lambda$ ) using the equation -

$L \lambda=M_{L} Q_{C A L}+A_{L}$

Where;

$\mathrm{L} 1=$ The spectral radiance at the sensor's aperture in $\mathrm{Wm}^{-2} \mathrm{sr}^{-1} \mu \mathrm{m}^{-1}$

$\mathrm{M}_{\mathrm{L}}=$ Band Specific Multiplicative Rescaling factor, gotten from the metadata of the image

$\mathrm{Q}_{\mathrm{CAL}}=$ Quantized and calibrated standard product pixel values (Digital Number)

$A_{L}=$ Band Specific Additive Rescaling factor, gotten from the metadata of the image

\section{STEP 2. Conversion from Spectral Radiance to At-Satellite Brightness Temperature}

Spectral radiance values for the bands were then converted to radiant surface temperature under an assumption of uniform emissivity using pre-launch calibration constants for the Landsat ETM+ sensor implemented into this equation;

$K^{2} \longrightarrow(K \underline{1}+1)-273.15$

$L \lambda$

Where;

$\mathrm{T}=$ At-satellite brightness temperature in Degrees Celsius

$\mathrm{L} \lambda=$ Spectral radiance in $\mathrm{Wm}^{-2} \mathrm{sr}^{-1} \mu \mathrm{m}^{-1}$ (gotten from equations 6 and 7)

$\mathrm{K}_{1}=$ Band specific thermal conversion constant from the metadata (K1_CONSTANT_BAND_X, $\mathrm{x}$ is the thermal band number)

$\mathrm{K}_{2}=$ Band specific thermal conversion constant from the metadata

(K2_CONSTANT_BAND_X, $\mathrm{x}$ is the thermal band number)

$-273.15=$ Constant for conversion from Kelvin to Degrees Celsius

STEP 3. Correcting for Land Surface Emissivity (LSE)

In estimating LSE, Normalized Differential Vegetative Index (NDVI) was utilized for emissivity correction. The temperature values obtained using Equation (8) are referenced to a blackbody. Therefore, corrections for spectral emissivity $(\varepsilon)$ became necessary according to the nature of land cover. This equation was used;

$\mathrm{e}=0.004 \mathrm{P}_{\mathrm{v}}+0.986$

Where, $\mathrm{e}=$ Land Surface Emissivity

0.004 and $0.986=$ Constants for emissivity estimation

$\mathrm{P}_{\mathrm{V}}=$ Proportion of vegetation given by the equation -

$$
\text { NDVI-NDVImin } 2
$$

$P V=(N D V I \max -N D V I \min )$

NDVI $=$ Normalized Differential Vegetation Index for each of the years

The index is defined by equation below -

$N I R-R E D$

$N D V I=$

$N I R+R E D$

$$
N I R+R E D
$$


Where NIR and RED are the reflectance in the near-infrared and red portion of the electromagnetic spectrum respectively.

For LANDSAT 5 TM and 7 ETM+,

$B A N D$ 4-BAND 3

$N D V I=$

$B A N D 4+B A N D 3$

Where Band 4 and Band 3 are the reflectance in the near-infrared and red portion of Electromagnetic spectrum of the Thematic Mapper and Enhanced Thematic Mapper respectively.

For LANDSAT 8 OLI,

$B A N D$ 5-BAND 4

$N D V I=$

BAND 5+BAND 4

Where Band 5 and Band 4 are the reflectance bands in the near-infrared and red portion of Electromagnetic spectrum of Operation Land Imager (OLI) sensor of Landsat 8 respectively.

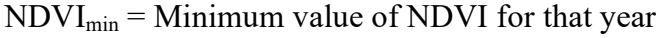

$\mathrm{NDVI}_{\max }=$ Maximum value of NDVI for that year

STEP 4. Estimation of the Land Surface Temperature

Finally, having corrected the emissivity in equation (4), the LST was estimated using the equation;

$L S T=B^{\underline{T} \times B} \underline{\underline{T} \times} \ln (\varepsilon)$

$$
1+w-P
$$

Where.

LST= Land Surface Temperature in Degrees Celsius

$\mathrm{B}_{\mathrm{T}}=$ At-satellite brightness temperature

$\mathrm{W}=$ Wavelength of emitted radiance $(\mu \mathrm{m})$

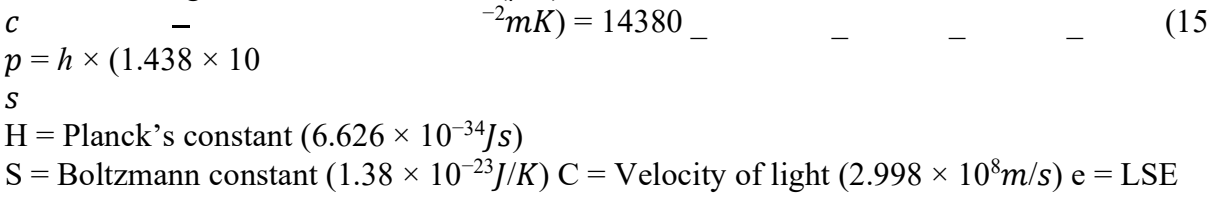

\subsection{Data Presentation and Analysis}

\subsubsection{Spatial and Temporal Variations in Land use and Land cover Pattern}

The total area in $\mathrm{km}^{2}$ of the study area is estimated to be about $108 \mathrm{~km}^{2}$. The land cover for each representative year per interval was classed into 5 classes - Water body, Urban Area, Bare Surface and Vegetative Cover. These classes were assessed for their spatial and temporal variations from 1986 to 2018 . The classes were further analysed to detect the changes that have occurred between them using Kappa statistic. According to Enaruvbe and Igeolumide(2014), an overall accuracy of $<50 \%$ is poor, $50-70 \%$ is moderate, while greater than $70 \%$ is considered good. Based on this, the kappa statistic was used to measure the magnitude of agreement between the reference and classified map (Viera et al., 2005). Kappa (k) is expressed as:

Kappa $(\mathrm{k})=\underline{\text { Observed Agreement }- \text { Expected Agreement }}$

$$
1 \text { - Expected Agreement }
$$

In 1986 (Table 2), the urban areas within Port Harcourt covered $20.22 \mathrm{~km}^{2}$ of the total study area (19\%), while water bodies account for $11.24 \mathrm{~km}^{2}(10 \%)$. bare surfaces took $14.97 \mathrm{~km}^{2}(14 \%)$ and vegetative cover, the largest of the classes for 1986 in terms of areal extent covered $61.71 \mathrm{~km}^{2}$, over half of the total area $(57 \%)$.

Table 2. Land use extents in 1986

\begin{tabular}{|c|c|c|}
\hline Class & Area (sq. km) & Percentage \\
\hline Water Body & 11.24 & 10 \\
\hline Bare Surface & 14.97 & 14 \\
\hline Vegetative Cover & 61.71 & 57 \\
\hline Urban Area & 20.22 & 19 \\
\hline
\end{tabular}




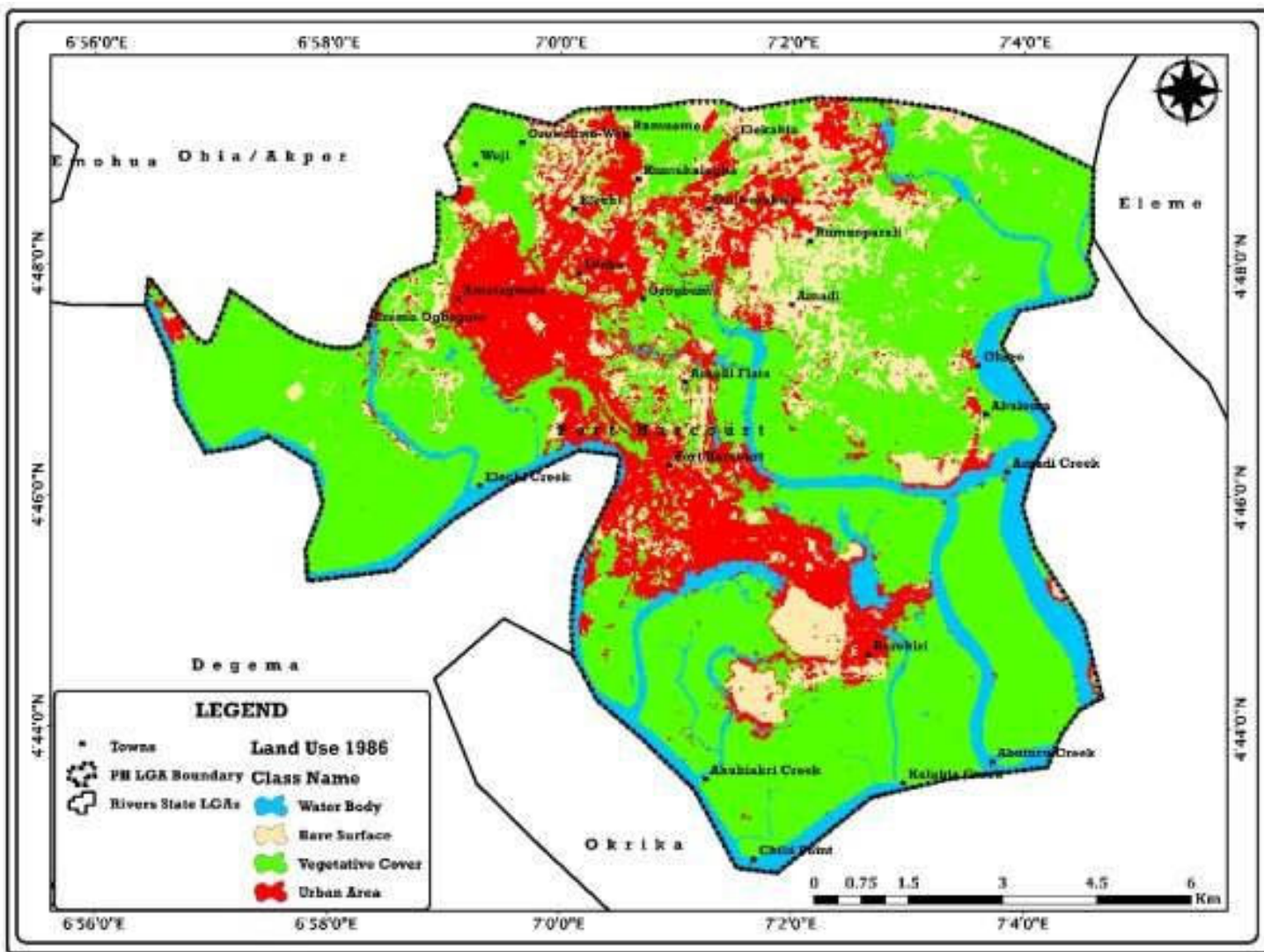

Figure 2. Port Harcourt Land Use in 1986

Figure 2 shows the spatial coverage of land use in Port Harcourt in 1986. It is observed here how vast vegetative cover was, given that the population boon experienced in the $21^{\text {st }}$ century had not yet occurred in this L.G.A. The urbanised areas were dense in towns like Amatagwolo, Port Harcourt, Diobu etc. Fig. 3 depicts the extent each class covers in 1986.

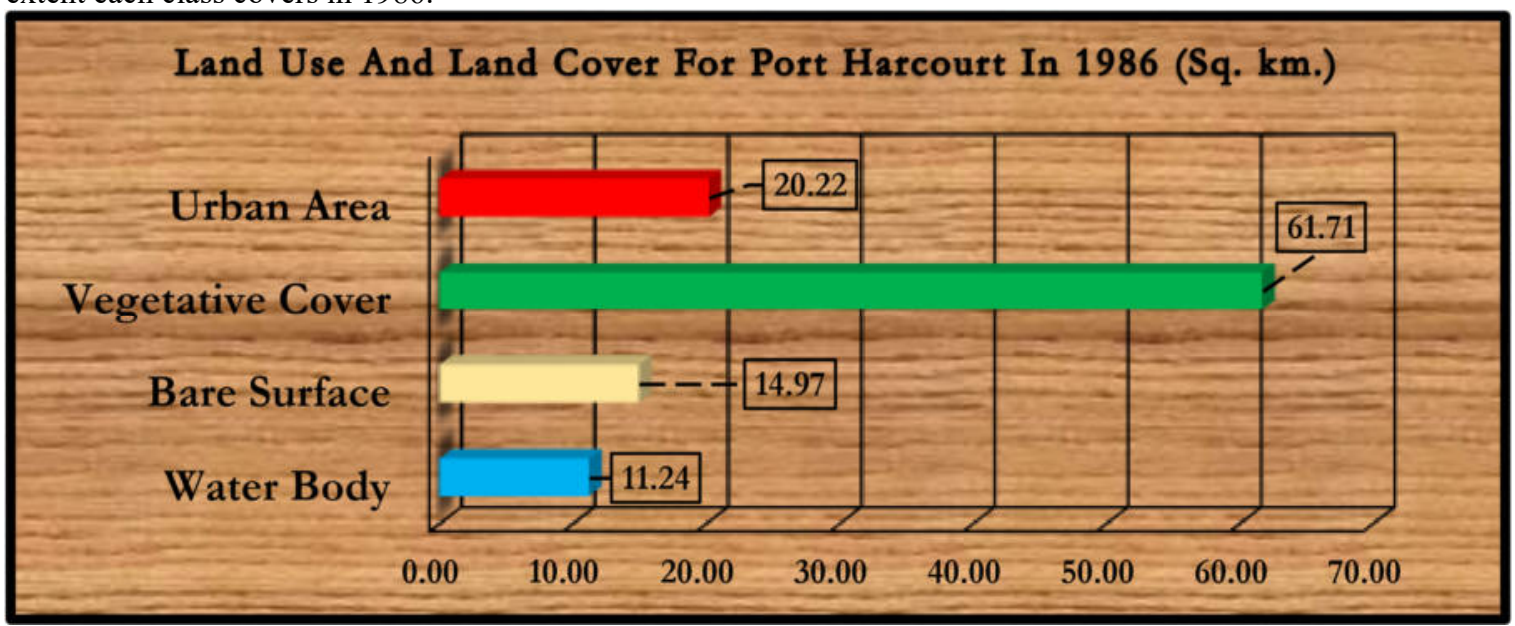

Figure 3. Land use extents in PH for 1986

The percentage covered per class is shown below in Fig 4.3, with vegetation displayed as the largest class within this period, and urbanised areas covering $19 \%$ of the study area. 


\section{Percentage of Study Area 1986}

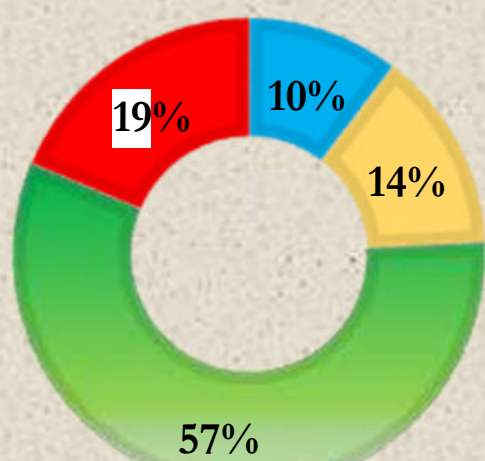

Figure 4. Percentage of Study Area covered in 1986

\subsubsection{Port Harcourt Land Use in 2003}

Urban areas increased to $38.02 \mathrm{~km}^{2}$ in 2003 , covering $35 \%$ of the total area (Table 3 ). The water bodies found in the area increased slightly to $15.32 \mathrm{~km}^{2}(14 \%)$, with bare surfaces covering an estimated $4.57 \mathrm{~km}^{2}(4 \%)$, an observed reduction from the past seventeen years. Vegetation, meanwhile, was covering an area of $50.23 \mathrm{~km}^{2}$ (46\%), with a significant reduction detected compared to 1986. This change was assessed using the formulae utilized by Kafi et al.,(2013) and Shalaby et al.,(2007) as shown below:

Where $\mathrm{A}=\%$ of change

$$
A=\frac{f-1}{1} * 100
$$

$\mathrm{F}=$ First date of imagery analysed

$\mathrm{I}=$ Reference date of the second imagery analysed

Table 3. Land use extents in 2003

\begin{tabular}{|c|c|c|}
\hline Class & Area (sq. km) & Percentage \\
\hline Water Body & 15.32 & 14 \\
\hline Bare Surface & 4.57 & 4 \\
\hline Vegetative Cover & 50.23 & 46 \\
\hline Urban Area & 38.02 & 35 \\
\hline
\end{tabular}




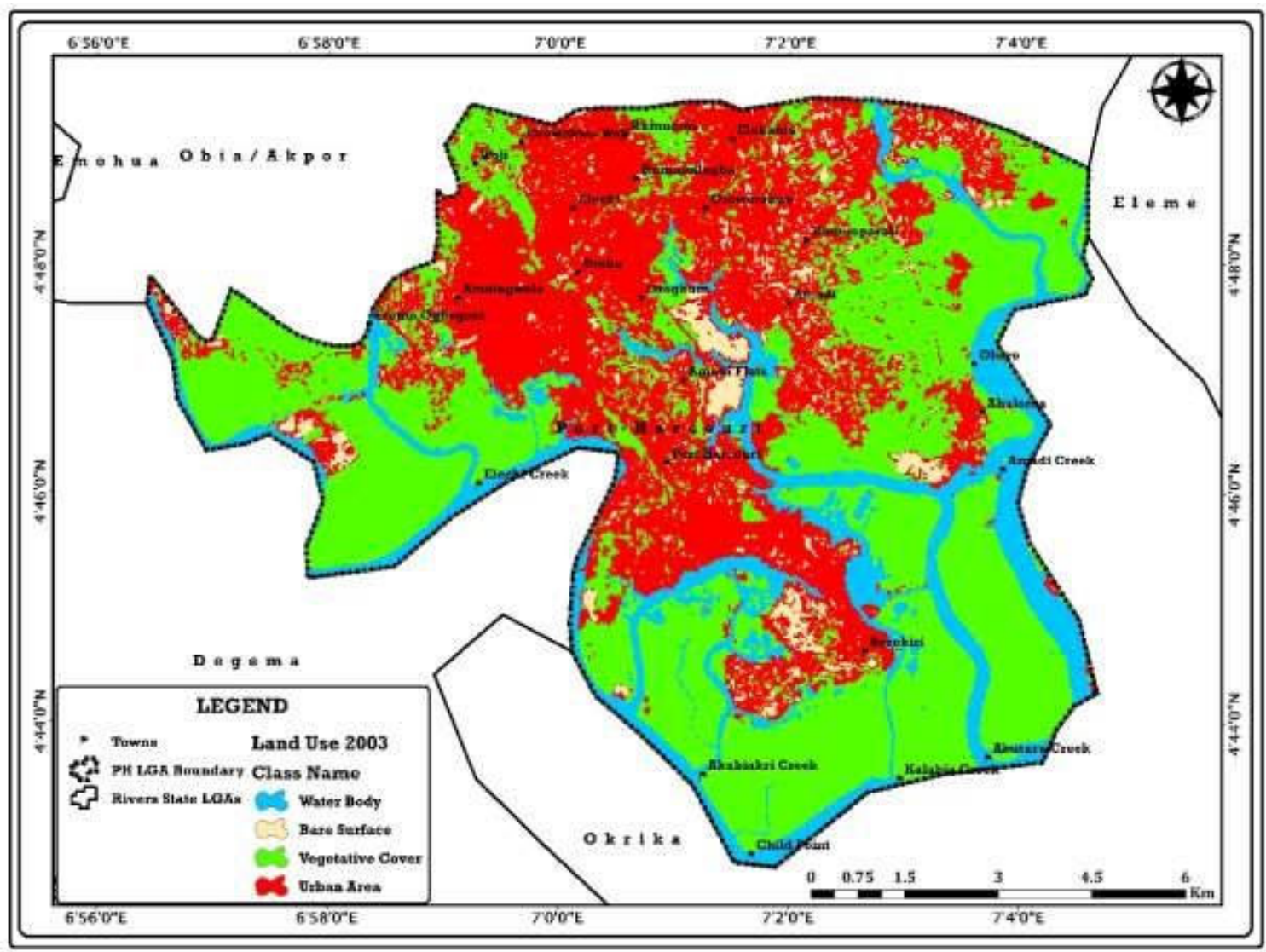

Figure 4. Port Harcourt Land Use in 2003

A visible increase in the extent of urbanisation is seen from Fig. 4. When compared to the map of 1986. Due to the growth of population, and Port Harcourt's growing reputation as an industrial and economic hub, urbanisation increased significantly to supply the demands of the population.

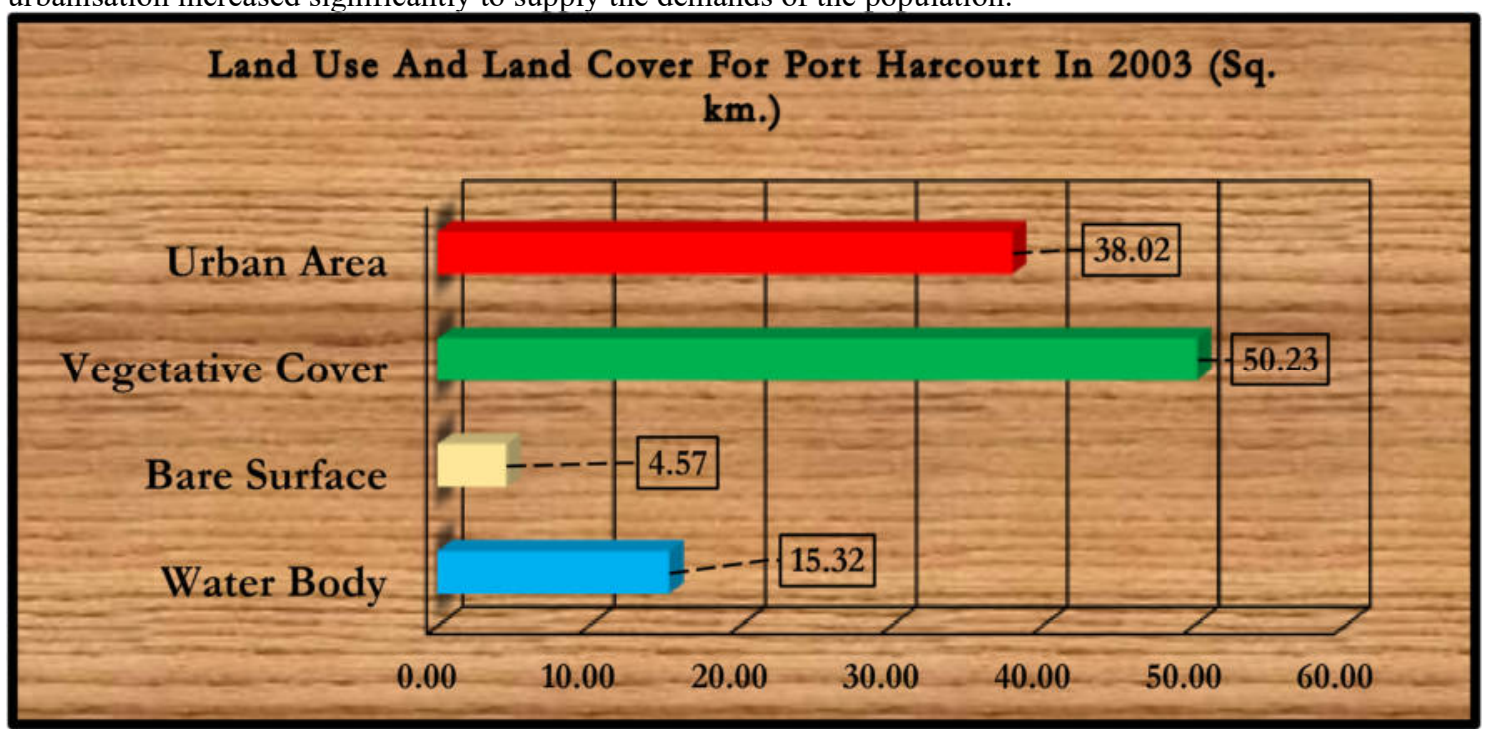

Figure.5. Land use extents in PH for 2003 


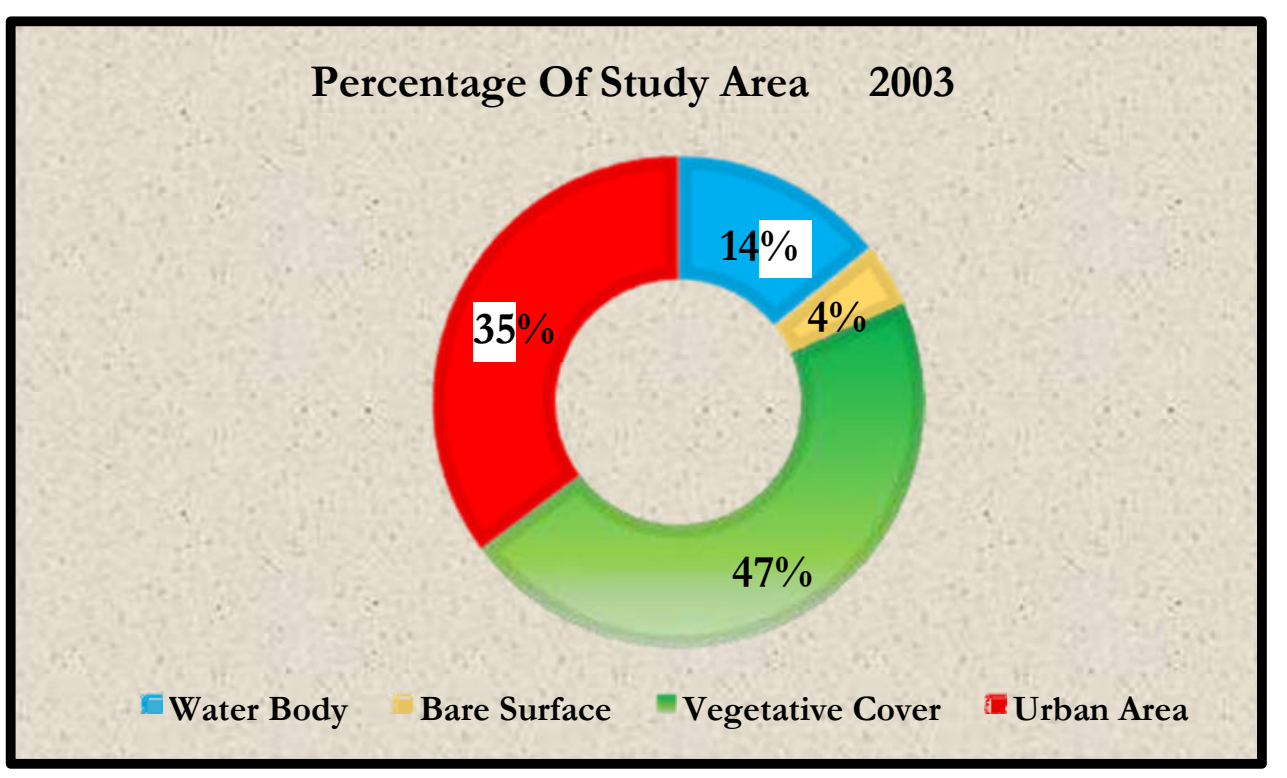

Figure 6. Percentage of Study Area covered in 2003

It is observed in Fig. 6 how much urban areas gained in percentage across the study area, with the visible reduction in vegetative cover equally detected.

1.7.3 Port Harcourt Land Use in 2018

By 2018, urban areas had increased significantly in size from 2003, covering $55.15 \mathrm{~km}^{2}(51 \%)$, over half of the entire study area (Table 4.3). Water bodies also increased to $19.68 \mathrm{~km}^{2}(18 \%)$. Bare surfaces reduced drastically to a mere $1.40 \mathrm{~km}^{2}(1 \%)$, with vegetation alarmingly dropping to $31.91 \mathrm{~km}^{2}(30 \%)$ when compared to 2003 .

Table 4. Land use extents in 2018

\begin{tabular}{|c|c|c|}
\hline Class & Area (sq. km) & Percentage \\
\hline Water Body & 19.68 & 18 \\
\hline Bare Surface & 1.40 & 30 \\
\hline Vegetative Cover & 31.91 & 51 \\
\hline Urban Area & 55.15 & \\
\hline
\end{tabular}




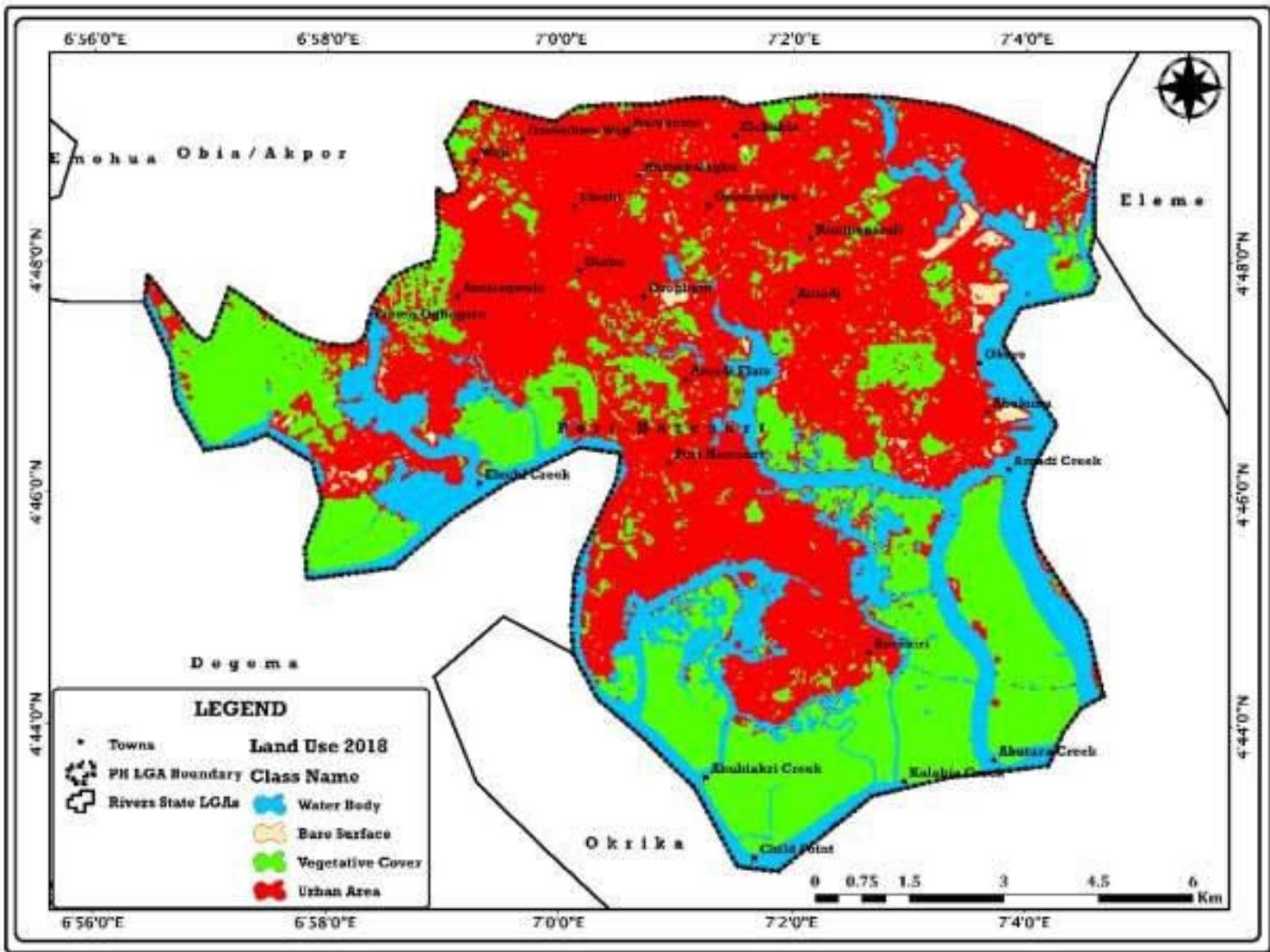

Figure .7. Port Harcourt Land Use in 2018

As observed from Fig. 7, the sharp increase in urban areas in Port Harcourt is depicted vividly, this being associated with the massive immigration into the area, with the reduction in vegetative cover also evident. Bare surfaces were almost non-existent during this period.

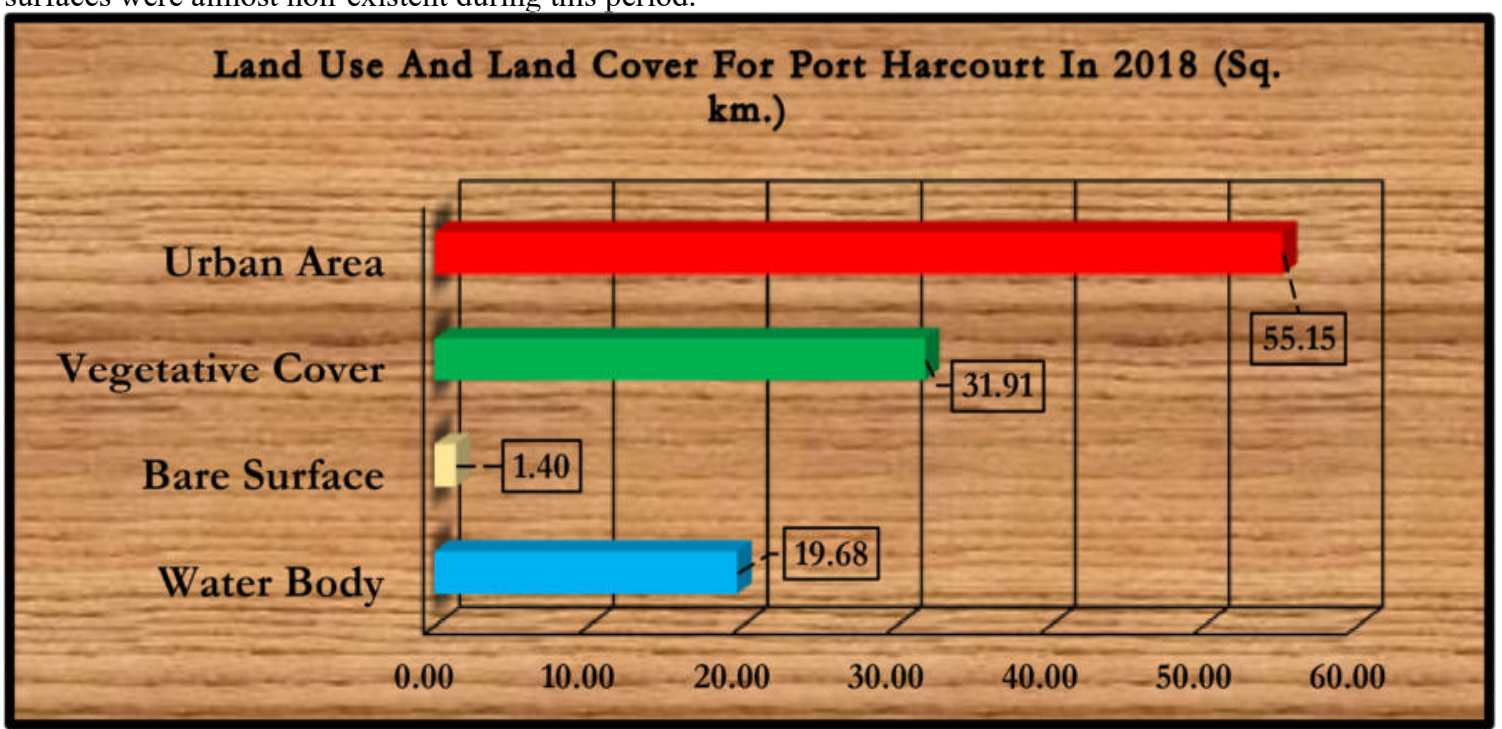

Figure.8. Land use extents in PH for 2018 


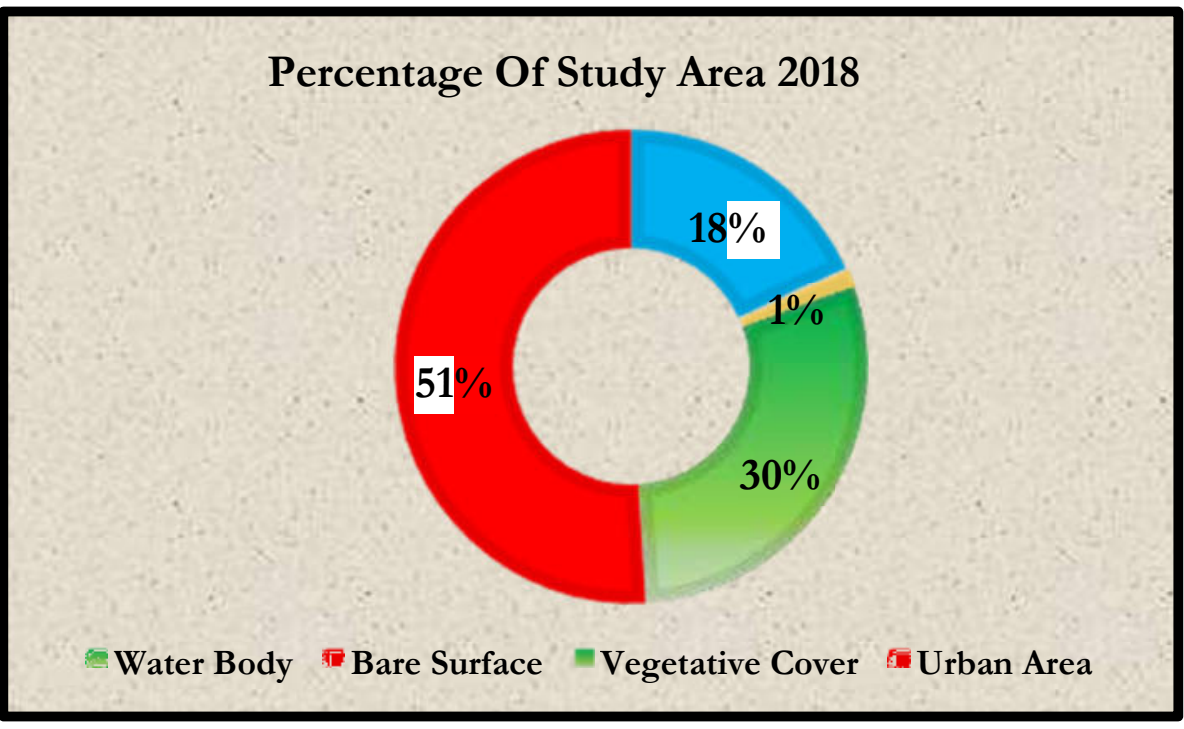

Figure.9. Percentage of Study Area covered in 2018

Urban areas had covered $51 \%$ of the entire study area, indicating a region in high risk of issues associated with increased urbanisation, such as air and water pollution, urban heat island, disease prevalence, urban flooding etc. It is even more indicting when it is observed that vegetative cover had reduced to a mere $30 \%$ of the study region.

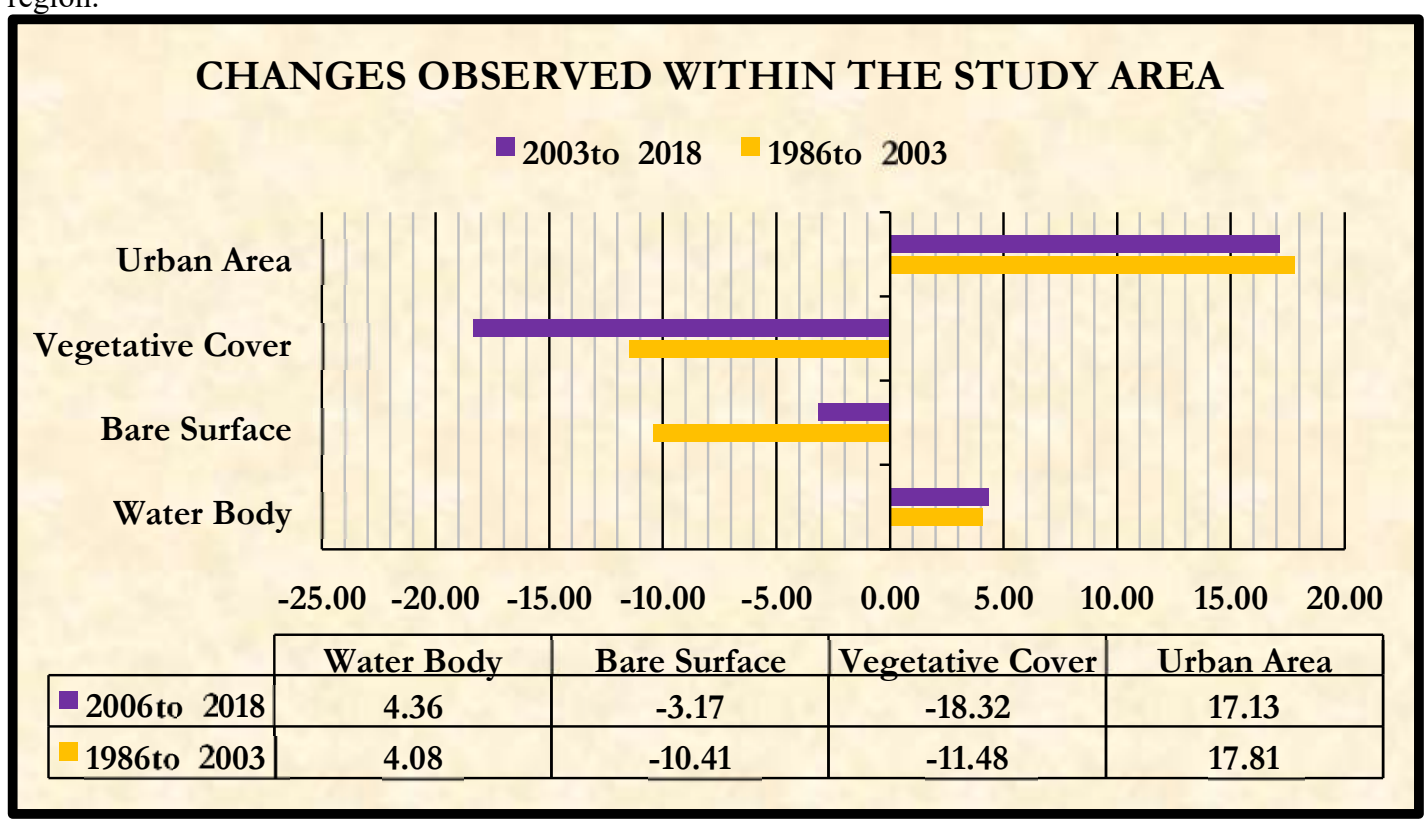

Figure .10. Changes observed in land use classes from 1986 - 2018.

From 1986 to 2003, urban areas increased significantly by $17.81 \mathrm{~km}^{2}$, due to expansion in residential areas coupled with increasing anthropogenic activities over the region resulting from dynamic population growth that occurred between these years (Fig. 10). The population growth and subsequent pressure for shelter by the inhabitants encouraged the development of extra settlements, and estates .Towns like Woji, Rumuoparali and Amadi were developed to aid combat this issue. However, from 2003 to 2018, a similar increase was observed as the urbanised regions grew by $17.13 \mathrm{~km}^{2}$. The prevalence of crude oil in Nigeria and the many opportunities this mineral resource presented led to an influx of inhabitants from the rural to urban regions and encouraged the government to further develop an already highly urbanised region. The bare surfaces within Port Harcourt underwent a total of 13.58 sq. km, of spatial loss from 1986 to 2018, with the most changes occurring from 1986 to 2003 . Over $10 \mathrm{sq}$. $\mathrm{km}$ of bare surfaces were lost during this period. Completion of government projects, filling of excavation and land filling sites likely contributed to the total loss observed by bare surfaces. Meanwhile, water 
bodies increased consistently from 1986 to 2018 , growing from 11.24 sq. km. in 1986 to 19.68 sq. km. in 2018 , a total change of $8.44 \mathrm{sq} . \mathrm{km}$. in increase. Land inundation due to increased water levels and climate change caused this rise in water body extent in Port Harcourt. Given that it is a coastal city, this phenomenon has a high likelihood of continuing, if adequate measures are not put in place to check this growth of water bodies.

Vegetative cover experienced losses in both periods as forested areas were cleared to claim land for developmental purposes. From 1986 to 2018, a total of 29.80 sq. km. of vegetative cover was lost, a direct consequence of the increasing built up areas. With the increase in population within the study area, vegetated regions were drastically transformed into built up areas to create extra provisions of shelter. A major consequence of this reduction in vegetated regions is the increase in surface and atmospheric temperature and the development of the Urban Heat Island (UHI), which has many negative effects on humans within that area. The extent to which this has occurred in Port Harcourt is determined in the subsequent sections below.

\section{Total Change Observed per Class within the Study Area from 1986 to 2018}

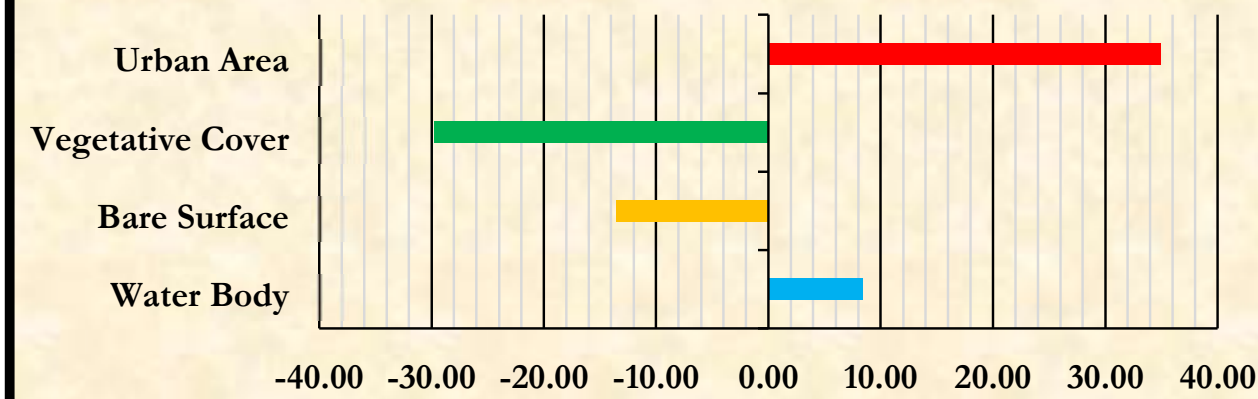

\begin{tabular}{|c|c|c|c|c|}
\cline { 2 - 5 } \multicolumn{1}{c|}{} & Water Body & Bare Surface & Vegetative Cover & Urban Area \\
\hline Total & 8.44 & -13.58 & -29.80 & 34.93 \\
\hline
\end{tabular}

Figure.11. Total Change observed from 1986 to 2018

Table.5. Changes in LST over the study period of the study area

\begin{tabular}{|c|c|c|c|}
\hline Time Period & $\begin{array}{c}\text { Maximum } \\
\left({ }^{0} \mathbf{C}\right)\end{array}$ & $\begin{array}{c}\text { Minimum } \\
\left({ }^{0} \mathbf{C}\right)\end{array}$ & $\begin{array}{c}\text { Mean } \\
\left({ }^{0} \mathbf{C}\right)\end{array}$ \\
\hline $\mathbf{1 9 8 6}$ & 24.8 & 16 & 20.6 \\
\hline $\mathbf{2 0 0 3}$ & 31.9 & 23.5 & 27.1 \\
\hline $\mathbf{2 0 1 8}$ & 38.3 & 24.3 & 33.2 \\
\hline \multicolumn{4}{|l|}{ Changes } \\
\hline $\mathbf{2 0 0 3}$ to 2018 & 7.1 & 7.5 & 6.5 \\
\hline
\end{tabular}

These results depict a worrying trend in surface temperature increase over Port Harcourt from 1986 to 2018 , as urban surfaces increase with time. These built-up areas in the cities will likely create unique micro-climate due to the replacement of natural vegetation with artificial surfaces. This affects temperature, wind direction and precipitation patterns, amongst other effects. The impact of heat waves is particularly strong in cities and towns which lead to decrease in water resource quality and quantity, decrease cold-related human morbidity and mortality along with reduced heating energy demand, and increase flood occurrences.

\subsection{Discussion of Findings}

Between 1986 and 2003, urban areas increased significantly by $17.81 \mathrm{~km}^{2}$ due to expansion in residential area coupled with increased anthropogenic activities over the region resulting from dynamic population growth that occurred between those years, and completion of development projects that were planned for that period. Vegetative cover lost a total of $11.48 \mathrm{~km}^{2}$, covering $46 \%$ of the study area by 2003 , having dropped from $57 \%$ in 1986. This indicated that forest resources have been on the degradation due to effects of climate change, farming, logging activities, woods for domestic uses, construction of urban areas and other anthropogenic factors. The effects might not be immediate but if not curtailed it could be devastating especially if carbon is not sunk through the forest, and this was depicted in the results of the land surface temperature analysis. During this period, the mean land surface temperature increased by $6.5^{\circ} \mathrm{C}$ from $20.6^{\circ} \mathrm{C}$ to $27.1^{\circ} \mathrm{C}$, an increase that was due to the growing urbanisation that occurred during this period. Built up areas were associated with average temperatures of $22.2^{\circ} \mathrm{C}$ 
in 1986 and $29.1^{\circ} \mathrm{C}$ in 2003, pointing to a strong relationship between LULC and LST and how surfaces with high albedo and low absorptivity reflect heat and contribute to the UHI development in an area. The coefficient of determination $\left(\mathrm{r}^{2}\right)$ for 1986 and 2003 were found to be 0.75 and 0.93 respectively, indicating very strong relationships between land use and surface temperature. Port Harcourt observed an increased temperature over the period due to the growing prevalence of impervious surfaces, and concurrent loss of vegetative cover over the study area, losing an effective natural mechanism of absorbing temperatures and cooling the atmosphere.

In the period between 2003 and 2018, the urban areas continued to increase, observing a transformation of $17.13 \mathrm{~km}^{2}$, covering $51 \%$ of the study area in 2018 , as urban population experienced a boon. The economic weakness in Nigeria and the world at large increased the prevalence of urban-rural migration, and led to the expansion of urbanised areas, as both the government and private individuals developed prior vegetated areas to cope with the population increase and provide shelter and services to the populace. Hotels and estates were erected as Port Harcourt grew its reputation as a tourist attraction, and an adequate location for improved economic standards. However, this urban expansion coincided perfectly with the massive reduction in vegetative cover observed within the study area from 2003 to 2018. This class lost a total of $18.32 \mathrm{~km}^{2}$ in the study area, as urbanisation continued to increase, and covered just $30 \%$ of the study area by 2018 . This period was characterized by intense deforestation and clearing of land for various developmental projects which is made evident by the level of increase in observed built-up areas, characterized by vegetal removal and the concomitant decrease in total vegetal cover (dense and riparian vegetations). This rapid depletion of vegetation cover has a wide range of impacts such as in the reduction of the natural cooling effects of shading and evapotranspiration of plants and shrubs. The analysis of the LST showed that the surface temperature increased on average by $6.1^{\circ} \mathrm{C}$, a slightly lesser increase than the one observed in the previous fifteen years. Nevertheless, the mean temperature increased from $27.1^{\circ} \mathrm{C}$ to $33 . .2^{0} \mathrm{C}$. The observed reduction of vegetation and the low albedo of urban surfaces are strong characteristics of this increased surface temperature and its associated UHI effect in Port Harcourt. Urban areas were associated with average temperatures of $29.1^{\circ} \mathrm{C}$ in 2003 and $34.3^{\circ} \mathrm{C}$ in 2018 , indicating a strong relationship between LULC and LST and how surfaces with high albedo and low absorptivity reflect heat and contribute to the UHI development in an area. The coefficient of determination $\left(\mathrm{r}^{2}\right)$ for 2003 and 2018 were found to be 0.93 and 0.94 respectively, indicating very strong relationships between land use and surface temperature.

\subsection{Conclusion}

The study area showed a significant growth on its urbanization trend between 1986 and 2018. This growth is mainly due to increased population, provision of more infrastructure, industries, etc. Vegetative cover and bare surfaces declined significantly between 1986 and 2018 due to more farming activities, population migration, and industrialization of the city. However, water bodies increased geometrically, signifying the presence of climate change in the study area. There was also an observed strong relationship between Land use Land cover and Land surface temperature in Port Harcourt city; as temperature tend to increase more in built up areas.

\section{REFERENCES}

Abd El-Kawy, O.R; Rod, J.K; Ismail, H.A;Suliman, A.S(2011). Land Use and Land Cover Change Detection in the Western Nile Delta of Egypt using Remote Sensing Data. Applied Geography,31:483-494.

Adinna, E.N, Enete, I.C and Okolie, T (2009). Assessment of Urban Heat Island and Possible Adaptations in Enugu Urban using Landsat/ETM. Pakistan Journal of Social Sciences, 6(1):26-31.

Du, J; Qian, L;Rui;Zuo,T;Zheng, D; Xu,Y;Xu,C.Y(2012). Assessing the Effects of Urbanization on Annual RunOff and Flood Events using an Integrated Hydrological Modelling System for Qinhuai River Basin, China. Journal of Hydrology,464-465:127-139.

Enaruvbe, G.O; Ige-Olumide, O (2004). Geospatial Analysis of land-use Change Processes in a Densely Populated Coastal City.The case of Port Harcourt, South-South Nigeria. Geocarto International, 30:441-456.

Enete, I.C, Awuh, M.E and Ikekpeazu, F.O (2014). Assessment of Urban Heat Island Situation in Doualla Metropolis, Cameroon. Journal of Geography \& Earth Sciences,2(1):55-77.

Kafi, K; Shafri, H; Shariff, A (2013). An Analysis of LULC Change Detection using Remotely sensed data: A case Study of Bauchi City. Earth \&Environmental Science, Beijing, China, 22-26 April. In Proceedings of the Top Conference Series.P.012056.

Nagi, R(2011).Classifying Landsat Image Servicies to make a Land Cover Map. Available online:http://blogs.esri.com/esri/arcgis/2011/05/28/ classifying-landsat-image-services-to-make -a-landcover-map/ (accessed on 10 May,2020).

Population Reference Bureau. (2010). Human Population: Urbanization. Retrieved from Population Reference Bureau: http://www.prb.org/Educators/TeachersGuides/HumanPopulation/Urbanization.aspx

Sarkar, H. (2004). Study of Landcover and Population Density Influences on Urban Heat Island in Tropical Cities by Using Remote Sensing and GIS:A Methodological Consideration”. London: Adventure Works Press.

Shalaby, A; Tateishi,R (2007). Remote sensing and GIS for Mapping and Monitoring Land Cover and Land-use 
changes in the Northwestern Coastal Zone of Egypt. Applied Geography, 27:28-41.

Singh, A(1989). Review Article Digital Change Detection Techniques using Remotely -sensed Data. International Journal of Remote Sensing, 10:989-1003.

Viera, A.J; Garrett, J.M(2005). Understanding Interobserver Agreement: The Vappa Statistic. Fam. Med, 37:360363.

Weng, Q., Lu, D., \&Schubring, J. (2004).Estimation of Land Surface Temperature-Vegetation Abundance Relationship for Urban Heat Island Studies.Remote Sensing of Environment, 467 - 483. Retrieved December 2017.

Zanganeh, S.S; Sauri, D; Serra, P; Modugno, S;Seifolddini, F;Pourahmad, A(2011). Urban Sprawl Pattern and Land-use Change Detection in Yazd, Iran. Habitat International, 35:521-528. 